University of Michigan Law School

University of Michigan Law School Scholarship Repository

\title{
Referendum as Applied to Proposed Amendments of the Federal Constitution
}

\author{
Ralph W. Aigler \\ University of Michigan Law School
}

Available at: https://repository.law.umich.edu/articles/881

Follow this and additional works at: https://repository.law.umich.edu/articles

Part of the Constitutional Law Commons

\section{Recommended Citation}

Aigler, Ralph W. "Referendum as Applied to Proposed Amendments of the Federal Constitution." Mich. L. Rev. 18 (1919): 51-4.

This Response or Comment is brought to you for free and open access by the Faculty Scholarship at University of Michigan Law School Scholarship Repository. It has been accepted for inclusion in Articles by an authorized administrator of University of Michigan Law School Scholarship Repository. For more information, please contact mlaw.repository@umich.edu. 
The Referendur as Applifd to Profosed Amendarents of the Federal Construtrios:- That various aspects of the fight against the National Prohibition (the ISth) Amendment would result in litigation was to be expected. The attack at present seems to be based on the use of the provisions for referendum found in a dozen or more of the states the votes of which went to make up the necessary three-fourths. Three very recent decisions or expressions of opinion by state courts of last resort are in this respect extremely interesting.

In Herbring v. Brown, 180 Pac. 328, decided April 29, 1919, the Supreme Court of Oregon in a mandamus proceeding refused tô order the Aitorney Genera! of that state to perform certain necessary functions prerequisite to the submission of the ratification of the 18th Amendment by the legislature to a vote of the people under the Referendum provision of the state constitution. On the other hand in State ex rel. Mullen v. Howell, I8r Pac. 920 (May 24, 1919), the Supreme Court of Washington in a similar proceeding ordered the Secretary of State to take the necessary steps for such submission. Finally, in Re Opinion of the Justices, ro7 At1. 673, (September, 1919) the Maine Supreme Court advised the Govemor of that state that the ratifi- 
cation of the I8th Amendment by the legislaure of Maine could not be referred to a vote of the people. Newspapers indicate other cases as pending.

In these three cases there are considered the two questions bound to rise in this connestion. Does the language of Article $V$ of the national constitution make the matter of ratification or rejection of proposed amendments a function of the Legislature, in the usual sense of that word? This, of course, is a federal question and until passed on by the United States Supreme Court must be considered as open. The second question is: Does the state provision for referendum cover the reference of acts of the legislature such as are consummated in ratifying a proposed amendment? This obviously is a local question, and the Supreme Court will not examine into the soundness of the conclusion of the state court. Davis v. Ohio, 24 U. S. 565 .

An answer to the first question depends upon the proper construction to be given to Article $V$ of the federal Constitution. This article which prescribes the method $0:$ amending the Constitution provides as follows: "The Congress whenever two-thirds of both houses shall deem it necessary, shall propose amendments to this Constitution, or, on the application of the legislatures of two-thirds of the several States, shall call a convention proposing amendments, which, in either case shall be valid to all intents and purposes, as part of this Constitution, when ratified by the legislatures of three-fourths of the several States or by conventions in three-fourths thereof, as the one or the other mode of ratification may be proposed by the Congress;" etc. In the Washington case above referred to, the court concluded that legislature 2s used in this Article $V$, does not mean necessarily the legislative assembly, that it is legislative power rather than legislative body that is meant. In arriving at this conclusion the court relies very largely upon what seems to be a wholly mistaken construction of the decision by the United States Supreme Court in Dasis v. Orio, 241 U. S. 565 .

It is important to determine just what the supreme court decided in that case. The Ohio legislature had passed an act redistricting the state for congressional representation. On proper petition under the Ohio referendum provision this act of the legislature was voted upon by the people and rejected. The Ohio Supreme Court in Staie ex ral. Davis v. Hildebrant, 94 Ohio St. 154, decided that the unfavorable vote had nuliified the action of the legislature. The United States Supreme Court affirmed this decision. The contention of the Jusing side was based, in part at least, upon the wording of $\S I V$, of Article I of the federal constitution which provides that "the times, places and manner of holding elections for senators and representatives shall be prescribed in each State by the legislature thereof; but the Congress may at any time by law make or alter such regulations except as to the places of choosing senators." It was argued that the word legislature made the action of the state legislature in the redistricting Act final. This contention was rejected but the Washington court at least seems to have failed to appreciate that the basis of this rejection was the part of $\S$ IV, Article I, following the semicolon. At the time of the adoption of the constitution it was a common practice among the states to elect the representatives to the national legisJative body at large. This practice continued in a number of states down to 
1842. In that year, Congress provided, acting under the part of $\S$ IV of Article $I$, following the semicolon, for the election of congressmen by districts. I Warson on ThE Constirution, 274. Unaer the Act of Feb. 7, 1891, Chap. 116, 25 Stat. 735, it was commanded that the existing districts in a state should continue in force "until the legislature of such state in the manner herein prescribed shall redistrict such state." By $\S$ IV of Chap. 5 of Act of Congress of Aug. 8, 1911 ( 37 Stat. 13), this was amended so as to provide that the redistricting should be made by a state "in the manner provided by the laws thereof." Mr. Chief Justice White in the Davis case said, "and the legislative history of this ant leaves no room for doubt that prior words were stricken out and the new words inserted for the express purpose, in so far as Congress had power to do it, of excluding the possibility of making the contention as to referendum which is now urged." See Cong. Rec., Vol. 47 , pp. $3436,3437,3507$. The only thing that the Supreme Court really decided in the Davis case seems to have been that there is nothing so far as the judiciary are concerned, about the initiative and referendum that destroys the republican form of government of the state which adopts such machinery in its lawmaking. Pacific Telephone Co. v. Oregon, 223 U. S. II8. The course, then, which the proposed redistricting in Ohio took seems to have been squarely in accord with the then provisions of Congress which in turn were expressly authorized by the latter half of $\S$ IV of Article $\dot{I}$ of the Constitution.

The argument that the word legislature as used in Article $V$ of the Constitution means the legislative body derives some support from the view which seems to have prevailed very generally prior to the 17 th amendment that United States senators could not constitutionally be elected by the direct vote of the people, the constitution providing expressly that senators should be elected by the "legislatures" of the several states. There can be no doubt that the word "legislature" had a perfectly well defined meaning to the framers of the constitution, and it would seem entirely clear that it was used in its then common sense. Terms of variable meaning according to circumstances as "commerce" and "due process of law" have been declared frequently not to have been used in a rigid sense; on the other hand a term such as "jury" is held to have been used in a fixed, non-elastic sense. The word "legislature" would seem more properly to fall within the latter class. See Winslow, C. J., in Borgnis v. Falk Co., 147 Wis. 327,348 et seq. See however, $R e$ Opinion of the Justices, I07 Atl. 705 (1919), where the Maine court said that despite the word "legislature" in Art. $2, \$ 1$, subd. 2 , the state referendum could be invoked as to a state act affecting the manner of choosing electors.

In the Maine case, the court took the view that in voting upon proposed amendments to the federal constitution, a state legislature is not acting in any legislative capacity but that its action is directly pursuant to the expression of the will of the people as stated in Article V. It is pointed out that the people might conceivably have provided for a state vote to be cast by either house of the legislative body alone, or by the governor, or in any other way that might have been designated. This view finds support in Dodge v. Woolsey, 18 How. 331; Eilingham v. Dye, 178 Ind. 336; 2 Warson on raE Con- 
Smiturion, 1310. See also 4 Elliott, Deb. 176, 177. Cf. Re Opirion of the Justices, 107 Atl. 705, supro.

The Oregon constitution providing for referring to a vote of the people "any act of the Legislative Assembly" is fairly typical of state referendum provisions. In Michigan it is declared that "Any bill passed by the legislature approved by the governor, except appropriation bills, may be referred," etc. The Nevada constitution provides for reference of any law or resolution. It is common knowledge that ratification of proposed amendments is by joint resolution, not by acl or bill. In the Oregon case the court concluded that this was sufficient to make the referendum provision inapplicable. On the other hand, the Washington court dealing with a referendum provision essentially the same, held the referendum properly made use of.

That a joint resolution is not an act or a bill in the normal sense of the words must have been known to the makers of the various constitutions. See Wru,Ard, Ifegrslative Handeuok; Chap. 5. However, such situations would not seem appropriate for strict, technical constructions, and if law is made by a joint resolution it would seem a not unreasonable contention that the referendum provision should apply. Such was the view of the Supreme Court of California in Hopping v. City of Richmond, 170 Cal. 605. Where a joint zesolution is used, as it often is, as an administrative measure of course there should be no reference unless such acts of the legislative body are clearly included. Even under the liberal view of the California case it would seem that the referendum would be inapplicable to votes on these proposed amendments, the action of the legislature not being properly legislative. See Ellingham v. Dye, sipra.

Indeed it might reasonably be doubted as to whether the question of effective ratification of proposed amendments, the counting of the votes by the states, is really a judicial question. The section quaranteeing a republican form of government is a familiar instance of a constitutional provision held not to faise a problem for the courts. Pacific Telephone Co. v. Oregon Supra. 